\title{
A New Phenomenon: Cohabitation outside Marriage
}

\section{By JARI LINDGREN}

The Population Research Institute

Premarital relations have always been rather common in Finland. Fines registers from parishes all over the country prove that sexual relations previous to marriage have been quite common during preceding centuries even if the church always opposed this custom. There are parish records according to which most of the bridal couples during certain years were sentenced to pay a fine for misusing the bridal crown i.e. concealing that the bride was pregnant at the time of the wedding. There are also parts in the country where it was rather uncommon to officially announce the engagement. A young couple did not announce their intention to marry until the bride was pregnant. It is also evident that in some parts of the country the bridal couple began to live together after the banns had been published (Nieminen 1951, 70-82).

Still in the beginning of the 1960's the proportion of firstborn children born within seven months after marriage was about 35 per cent. A declining tendency began during the last years of the 1960's. In 197732 per cent of all brides were pregnant when marrying.

At the same time as the proportion of marriages of pregnant women decreased the number of children born out of wedlock has grown. In the 1950's the proportion of children born out of wedlock was yearly between four and five per cent of all live births. In the mid 1960's this proportion began to increase. From 1966 to 1977 it more than doubled from 5.0 to 11.2 per cent (Table 1).

In spite of the continued increase of children born out of wedlock nuptiality remained high during the 1960's. From 1971 on, however, the marriage rate began to go down.

T a b le 1. Proportion of children born out of wedlock.

$\begin{array}{lrrr} & \text { Per cent } & \text { Per cent } \\ 1961 & 4.3 & 1970 & 6.2 \\ 1962 & 4.2 & 1971 & 5.5 \\ 1963 & 4.3 & 1972 & 6.7 \\ 1964 & 4.6 & 1973 & 7.9 \\ 1965 & 4.8 & 1974 & 9.0 \\ 1966 & 5.0 & 1975 & 10.1 \\ 1967 & 5.3 & 1976 & 10.9 \\ 1968 & 5.3 & 1977 & 11.2 \\ 1969 & 5.9 & & \end{array}$


The change in the number of marriages or in the crude marriage rate does not give a fair picture of the changes in nuptiality as the size of the marriageable age groups has altered significantly. At the end of the 1960's the large age groups born after the Second World War reached the age of 20-24 years which shows the highest nuptiality in Finland nowadays. This age group which represented a very high marriage intensity continued to be numerous even in the beginning of the 1970's. Hence the decline in the number of contracted marriages in the beginning of this decade can hardly be explained only by changes in age structure.

In order to eliminate the effects of changes in age structure the actual numbers of marriages of women in the 1970's were compared with the imputed numbers of marriages according to the nuptiality rates of 1970 (Table 2).

$\mathrm{Table} 2$. Actual number of first time married and remarried women and the imputed number of corresponding marriages in 1971-77 if nuptiality had been the same as in 1970 .

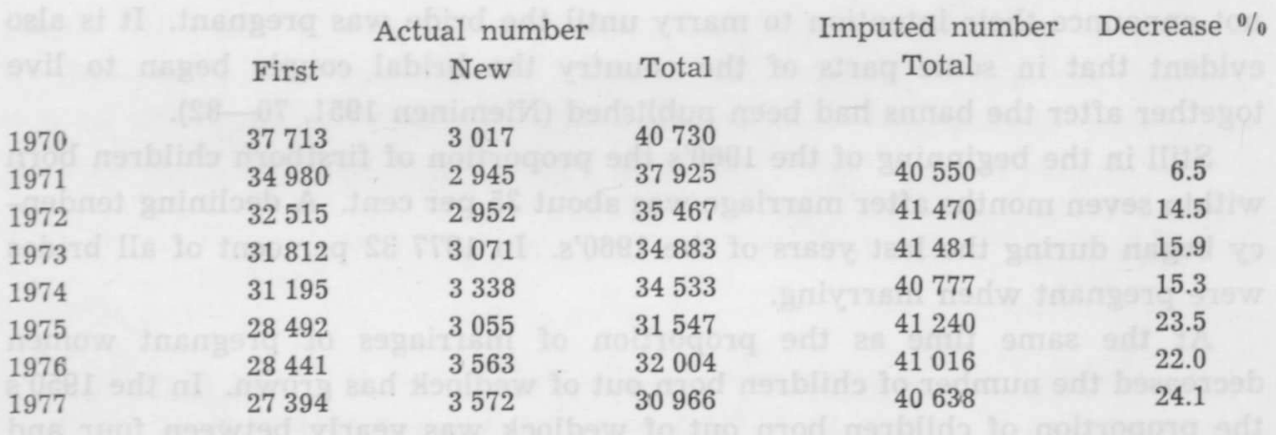

It appears that the difference between the actual and the imputed numbers of marriages grew every year. In 1977 the actual number of first marriages was 24 per cent smaller than in the case that nuptiality had been the same as in 1970 .

The decrease in nuptiality in the 1970's does not imply automatically that the difference between actual and imputed marriages are consensual unions. External factors such as trade cycles and changes in marriage patterns could effect the intensity to marry.

The decrease of nuptiality is a consequence of the fact that the large age groups postponed having children because of the hard competition in education, work and housing they experienced until they found their place in society.

The data presented above on nuptiality and fertility prove indirectly that something new has been going on in the marriage pattern in the 1970's. Until now very little has been known about the frequency of consensual unions and still less about motives and implications. An idea of at least the frequency of consensual unions in Finland is given by a study made by the Central Statistical Office of Finland in 1978 (Aromaa, K. et al., 1979). According to this study 
about five per cent of the population above 15 years of age or about eight per cent of all persons living in conjugal unions - marriages and consensual unions - form a consensual union.

Most spouses in the consensual unions were rather young. One third of the 15-24 age group of which 23 per cent lived in a conjugal union were in consensual unions (Table 3 ). In the following age group 25-44 years consensual unions represented less than ten per cent. Most of the individuals belonging to this age group or three fourths lived in a conjugal union.

$\mathrm{T}$ a ble 3. Proportion of consensual unions of all conjugal unions.

\begin{tabular}{lrr} 
Age group & $\begin{array}{c}\text { Consensual unions } \\
\%\end{array}$ & N \\
& & \\
$15-24$ & 33 & 272 \\
$25-44$ & 8 & 487 \\
$45-64$ & 3 & 375 \\
$65-$ & 2 & 166 \\
\hline & & 1300
\end{tabular}

About nine tenths of all individuals living in a consensual union were workers or lower civil servants while only about one half of the whole population belongs to these occupational groups. Consensual unions are definitely more common among the best-educated (Table 4). People with the most education also make up the youngest group. Because reforms in society occur via vanguard groups, typically the most-educated groups, it can be predicted that the prevalence of consensual unions in these groups means that this form of family life will become more common in Finnish society. These results pertaining to education differ clearly from the situation in Sweden, where it has been found that consensual unions are more common the less basic education the person has. One reason for this may be that consensual unions are more common in Sweden than in Finland and have therefore already spread to all social classes (Aromaa, K. et al. 1979).

Having children in a consensual union does not seem to be common, only one third of the couples had children. According to the family statistics pub-

$\mathrm{T}$ a ble 4. Experience of having lived in a consensual union according to education.

Lower level of basic school or less

Higher level of basic school

$8 \%$

Lower level of secondary school or of vocational training

$8 \%$

Higher level of secondary school or higher education 
lished by the Central Statistical Office in 1977 only 1.3. per cent of all families with children were non-married parents who had a child together, totalling merely 11600 (Tilastokeskus 1979).

Even if one has very few statistical data on the stability of consensual unions it seems that most consensual unions end in a contracted marriage. According to unpublished data from the above mentioned study 47 of 100 consensual unions had ended in marriage and 13 in separation (Suominen 1979, 11). It is after all easier to live in a marriage automatically regulated by law in almost all conceivable situations.

However, legislation has gradually taken into consideration the fact that people live in consensual unions. Deficiences have gradually been corrected. Thus e.g. a new law has been enacted according to which both parents are responsible for the maintenance of the child be it born to married or unmarried parents. Even the social security of unmarried couples has been ameliorated. Housing subsidies are paid to couples living together out of wedlock with at least one child in the care of the head of the household. Further, unemployment assistance is paid to a breadwinner living in a consensual union just as to a married one if the couple have a child together. Consensual unions and married couples are also taxed in an equal way if they have a child.

In some cases consensual unions are still in a poorer position than married ones. A widow does not receive any pension after the death of her spouse in a consensual union; if one of the partners dies the surviving partner cannot inherit the deceased one without a will etc. On the other hand there are situations when living in a consensual union is economically more profitable than being married. If e.g. a widow contracts marriage her right to a widow's pension expires. This is, however, not the case when she enters into a consensual union, as a consensual union is not considered a legal one.

According to a small study from the city of Tampere among the reasons for forming a consensual union the most common one was the wish to know each other better. Hence the union could be considered having the same goal as engagement which according to the motivations of the existing marriage law was to give the persons who aim to marry an opportunity to get acquainted with each other (Komiteanmietintö 1972). Another important reason for forming a union was loneliness. In Finland where internal migration during the past decades has been very intense this reason seems to be rather plausible (Sihvo 1976). Young people were forced to move to places far away from their homes to study and work.

The reasons for changing the consensual union into marriage in the Tampere study was mostly the feeling of security in general but especially regard for children.

The custom of living in a consensual union came later to Finland than to the other Scandinavian countries. The most important reason could have been the strong structural change that Finland experienced after the Second World War and which extended to the beginning of the 1970's. This period 
was characterized by extensive industrial changes with profound demographic effects. From 1950 to 1975 the proportion working in agriculture in the economically active population was reduced from 46 per cent to 15 per cent and resulted in intensive migration to urban centers. Often the newcomers had difficulties in adjusting to the new places of arrival. This process of transformation might have been one important reason why the new ideas of sexual life and cohabitation disseminated more slowly in Finland than in the other Nordic countries.

Living in consensual unions has become more and more common. However, they still form rather a small fraction of all unions, much smaller than in the neighboring country of Sweden. Even if one does not have any statistical facts about the stability of the consensual unions it is evident that in most cases consensual unions end in marriage, at least among young people not previously married. In this case the consensual union might first of all be considered a form of engagement unaccepted by earlier generations but suitable for the modern liberal idea of sexual life. Another category of individuals frequently living in consensual unions are divorced persons who might often insist on cohabitation without marriage, partly perhaps, because a contracted marriage will weaken their economical situation, e.g. pensions will be reduced etc. In the rural areas a type of consensual union known from olden times has been a couple from two different social classes, most commonly the owner of a farm and the farm's hired girl, who live together in a marriage-like situation without legally marrying. However, this category forms only a small fraction of all consensual unions.

For the present there is no uniform definition of a consensual union. The idea of what could be considered as a consensual union is precarious and the regulations vary from one field of social policy to another. Living in a consensual union is mainly to be considered a form of engagement which ends in marriage. In the long run the differences between living in a marriage and a consensual union will be smoothed out by incorporating the consensual union in legislation. As this form of cohabition is gradually put on equal footing with common law marriage it seems evident that living in consensual unions does not cause any major disturbances either for the individuals concerned or for society.

\section{References}

Aromaa, K.-Cantell, I.-Jaakkola, R.: Parisuhde yhä useammin virallisesti vahvistamaton. Sosiaalinen Aikakauslehti no 1, 1979, pp. 46-50.

Komiteanmietintö 1972 A 21, Avioliittolakikomitean mietintö I, Helsinki 1972.

Nieminen, Armas: Taistelu sukupuolimoraalista, Turku 1951.

Sihvo, Jouko: Avioliitto ja avioero, Kirkontutkimuslaitos, sarja A No 30. 1976.

Suominen, Leena: Lapsiperhe Suomessa. Väestöliitto. Kolmikanta-sarja. Helsinki 1979.

Tilastokeskus: Perhetilasto 31. 12. 1977. Tilastotiedotus VA 1979: 6, Helsinki 1973 